\title{
AN ANALYSIS OF CONJUNCTIONS FOUND IN BARACK OBAMA'S FAREWELL SPEECH TEXT
}

\author{
Sulistyaningsih ${ }^{1}$ \\ ${ }^{1}$ (STKIP PGRI Sidoarjo/sulistyaningsih3112@gmail.com) \\ Joko Slamet ${ }^{2}$ \\ 2(STKIP PGRI Sidoarjo/ joko.slamet2801@gmail.com)
}

\begin{abstract}
In communication people use conjunctions in their speech, so did Barack Obama in his farewell speech. His speech consists of many various conjunctions that will be interesting to study to understand the connection between the sentences delivered by Him. The purpose of this study is to find out types of conjunction especially external conjunction, internal conjunction, and continuatives in Barack Obama's farewell speech text based on semantics naming. It used the descriptive qualitative method. The instruments were researchers themselves, table, Barack Obama's speech text. The data collection were taken from were taken from the internet, it was the President of the United State of America (period: 2009-2017) Barack Obama's speech text of his farewell in Chicago. To analyze all data, this study used the theory of conjunction by Martin and Rose (2007). The data were identified types of conjunction, then were classified, were displayed, and were described. The finding out of words that were analyzed conjunctions and continuatives were 18 (eighteen) types of external conjunctions, 8 (eight) types of internal conjunctions and 3 (three) continuatives.
\end{abstract}

Keywords:

External Conjunction, Internal Conjunction, Continuative, Speech

DOI:10.19105/ojbs.v12i2.2013

\section{A. Introduction}

The word "Conjunction" derives from Latin "Conjunction" which means a joining together. A conjunction is a word that links words, phrases, or clauses. It is a way of linking different parts of text to create cohesiveness. It is difficult to learn to use conjunctions correctly in a foreign language as in English Language. Halliday and Hasan stated that most English conjunctions have several different functions and these may correspond to several different conjunctions in another language. ${ }^{1}$ Conjunction plays an important role in communication. It acts as a link or connector between the clauses. ${ }^{2}$ Conjunction also combines a set of

\footnotetext{
${ }^{1}$ M. A. K. Halliday and Ruqaiya Hasan, Cohesion in English (London: Longman, 1976), 277.

2 Heidi Lorimor, "Conjunction and Grammatical Agreement" (Dissertation, University of Illinois at Urbana-Champaign, 2007).
} 
grammatical functions into larger grammatical units. This is claimed by Ramlan, ${ }^{3}$ conjunctions are words that connect words, parts of sentences, and sentences.

The function of conjunctions is to join any of the following language units such as word, clause, sentence, and phrase to another as quoted by Stern. ${ }^{4}$ It means the function of conjunction can be used to join with words, sentences, clauses, and phrases. Bloor, T. and Bloor, M. said that the functional analysis of English is the analysis and description of English using functional linguistic system. ${ }^{5}$

In communication people use conjunction, both in spoken language and written language. This study is focused on the analysis of the conjunctions used in the speech text, in this case, the speech text as the data. The speech text that was selected as data source is Barack Obama's farewell speech. President Obama is a public figure and his speech can influence people all over the world. One of Obama's speeches texts was delivered in Chicago.

Barack Obama's farewell speech text was chosen as a media of the analysis because this speech consists of many various conjunctions to join parts

\footnotetext{
${ }^{3}$ M. Ramlan, Morfologi Suatu Tinjauan Deskriptif (Yogyakarta: CV. Karyono, 1985), 13.

${ }^{4}$ George Stern, An Outline of English Grammar: With Exercises and Answer Key (Singapore: Learners Pub., 2003), 101.

${ }^{5}$ Thomas Bloor and Meriel Bloor, The Functional Analysis of English (London: Arnold, 1995).
}

of speech, phrases, and clauses. It is interesting to be analyzed the types and the functions of conjunctions in Obama's speech since his used all of the conjunction related to this study. So it will help us easier to understand the connection of the sentences.

The purpose of this study is to find out types of conjunction especially external conjunction, internal conjunction, and continuatives in Barack Obama's farewell speech text based on semantics naming. So, the significance of this study will be able to use as a reference by English Department students to understand more about conjunction.

\section{B. Method}

The writers applied descriptive qualitative research for completing this study. The data were taken from speech text using conjunction contained in Barack Obama's farewell speech. The data were taken from the speech text where some conjunctions were found in the speech text.

To collect the data, searching and downloading the script of Barack Obama's speech text, then, the writers printed out and read the speech to make effective in the analysis. The third step, the writers identified all the data by giving highlight and underline in every conjunction which appeared in the speech. The fourth step, the writers made a list the conjunctions to be analyzed. 
After collecting the data, identifying and classifying every conjunction which consists of external conjunction, internal conjunction or continuatives was the first step done by the writers. The second step, the writers described and explained the types of conjunction. Then, to analyze the types of conjunction which appear in the speech text the writers used Martin and Rose's theory. ${ }^{6}$ This was supported by Hameed, through a kind of analysis of an English text can be found conjunction, substitution, ellipsis, and lexical cohesion. ${ }^{7}$ The last step, the writers concluded the finding types of the conjunctions in the speech text. Then, the writers made the conclusion based on the concrete of the data in this study.

\section{Results}

After all of the data were identified then were classified based on the each types of conjunction, all of them would have been analyzed.

\section{Analysis of External Conjunction}

All of the data which were consisted of external conjunction clearly described in the table below.

Table 1. Types of external conjunction

\begin{tabular}{|c|c|c|}
\hline $\begin{array}{c}\text { External } \\
\text { Conjunction }\end{array}$ & Linkers & Number \\
\hline
\end{tabular}

6 J. R. Martin and David Rose, Working with Discourse: Meaning Beyond the Clause, 2nd ed. (London: British Library, 2007).

7 Hind Tahseen Hameed, "Cohesion in Texts: A Discourse Analysis of a News Article in a Magazine," Al-Faith Journal 37 (December 2008): 81-114.

\begin{tabular}{|c|c|c|}
\hline $\begin{array}{c}\text { External } \\
\text { Addition }\end{array}$ & $\begin{array}{c}\text { And } \\
\text { Or }\end{array}$ & $\begin{array}{c}190 \\
29\end{array}$ \\
\hline External & But & 39 \\
Comparison & $\begin{array}{c}\text { In other words } \\
\text { Instead of }\end{array}$ & 1 \\
& After & 2 \\
\hline & When & 14 \\
External Time & While & 2 \\
& & 15 \\
& Because & 1 \\
& However & 8 \\
& So & 1 \\
External & Although & 7 \\
Bonsequence & By & 11 \\
& If & 1 \\
& Unless & 2 \\
& Without & 6 \\
& To & 10 \\
& & \\
& &
\end{tabular}

\section{a. External Addition}

In addition relation, there are two sub-types namely addition and alternation. The following excerpts provide example of External

\section{Addition}

"My fellow Americans, Michelle and I have been so touched by all the well-wishes that we've received over the past few weeks."

The data above explained that and as a conjunction relation to connect one word to join with another one to synchronize a sentence. As we could see that the data showed the same idea one another because the words

8 "President Obama's Farewell Address: Full Video and Text," The New York Times, January 20, 2018, sec. U.S., https://www.nytimes.com/2017/01/10/us/politics/o bama-farewell-address-speech.html. 
Michelle and I had same meaning as pronoun in this sentence. Then the conjunction and could build the sentence to be clear. If and was deleted from the sentence, it would be unclear.

"...the American people -- in living rooms and in schools; at farms and on factory floors; at diners and on distant military outposts..."9

The data above showed that and as an additive conjunction which we probably applied in a sentence to correlate one adverb of place to join with another one to get a proper sentence. Even though both in living rooms and in schools had the same meaning which explained about the place, the use of and conjunction could complete the sentence so that it could be understood clearly.

"Only if all of us, regardless of party affiliation or particular interests help restore the sense of common purpose that we so badly need right now." 10

In the data above, "or" conjunction was used as the choice they really needed. In this case, "or" conjunction showed the possibility two phrases. The first is regardless of party affiliation while the second one is particular interest help.

\section{b. External Comparison}

The following excerpts provide example of External

\section{Comparison:}

"My fellow Americans, Michelle and I have been so touched by all the well-wishes that we've received over the past few weeks. But tonight it's my turn to say thanks."11

The data above show that but as contrastive relation between one statement with the other statement. The conjunction but is used to clarify difference of statements. The differences of statements clearly mention in data above to show but are correlation with some statements to explain some different statements to be one unit of a proper sentence.

"In other words, it will determine our future. To begin with, our democracy won't work without a sense that everyone has economic opportunity."12

The data above show that in other words as conjunction to connect one statement to join with another statement which has different meaning. In other words the above excerpt clarified that there are some statements to join with the conjunction in other words. So, the data above has meaning as dissimilarity statement but in the same contexts.

"And increasingly we become so secure in our bubbles that we start accepting only information,

\footnotetext{
9 "President Obama's Farewell Address."
}

10 "President Obama's Farewell Address."

11 "President Obama's Farewell Address."
12 "President Obama's Farewell Address." 
whether it's true or not, that fits our opinions, instead of basing our opinions on the evidence that is out there."13

In external comparison, one meaning can be replaced by another using instead of. In this circumstance, the conjunction instead of was used to replace the meaning of the second phrase that is based on our opinions at the evidence that is out there.

\section{c. External Time}

"There's a second threat to our democracy. And this one is as old as our nation itself. After my election there was talk of a postracial America." ${ }^{14}$

The conjunction after in the data above showed the sequence of what happened after the election occurred. The conjunction after in data above has a meaning to clarify another statement still has correlation with previous statement.

\section{d. External Consequence}

\section{1) Cause}

"You can tell that I'm a lame duck, because nobody is following instructions." ${ }^{15}$

It showed that because is presupposing a reason of the sentence above. To show of presupposing a reason in data above is visible in the end of the

\footnotetext{
13 "President Obama's Farewell Address."

14 "President Obama's Farewell Address."

15 "President Obama's Farewell Address."
}

sentence. Therefore, for this case because has a meaning as result of presupposing a reason that is "You can tell that I'm a lame duck".

"And such a vision however well intended, was never realistic. Race remains a potent...... and often divisive force in our society." 16

The data above show however in the middle of one unit of sentence and however above similar function with but. The conjunction however has different meaning with but so, there is no reason from explanation above that the conjunction however has the same meaning with the conjunction but. But, in the data above, it showed the contrast between the phrases with another and usually the conjunction however is used in the formal situation.

"So I first came to Chicago when I was in my early twenties, and I was still trying to figure out who I was; still searching for a purpose to my life."

In the statement above, Obama used the conjunction so in the beginning of his sentence to start his explanation about his life when he first came to America. The conjunction so showed the correlation between the first 
statement and the next one to clarify everything about the journey of his life.

"And although..... Boston and
Orlando and San Bernardino
and Fort Hood remind us of how
dangerous radicalization can
be, our law enforcement
agencies are more effective and
vigilant than ever. We have
taken out tens of thousands of
terrorists, including Bin
Laden."17

The conjunction although in the data above is cohesive because, although is occurring in the beginning of the sentence followed by and after a full stop. The data above showed although as subordination in the sentence. It explained that. So, in the data above although as relation to give a meaning is being a comparison in same context.

\section{2) Means}

"The answer to people's hopes and, because of you, by almost every measure, America is a better, stronger place than it was when we started." ${ }^{18}$

The conjunction by was used to express means. Here, Obama made sure that America is a better, stronger place that it was when they started. To achieve those purpose, they needed to do an action which is act in almost every measure.

\section{3) Condition}

"If every economic issue is framed as a struggle between a hardworking white middle class and an undeserving minority, then workers of all shades are going to be left fighting for scraps while the wealthy withdraw further into their private enclaves."

In the data above, the conjunction if-then was used to realize one condition. Both conjunction if and if-then actually had same meaning but when we used the conjunction if-then, the condition which might occur would be focused.

\section{4) Purpose}

"And so we're going to have to forge a new social compact to guarantee all our kids the education they need. To give workers the power...... to unionize for better wages. To update the social safety net to reflect the way we live now." ${ }^{20}$

In the data above, the conjunction which was used to express purpose was the conjunction to.

\section{Analysis of Internal Conjunction}

It was found in this research that there were eight linkers of internal conjunction which were appeared in the Barack Obama's farewell speech. All of the conjunctions could be seen on the table below.

\footnotetext{
17 "President Obama's Farewell Address."

18 "President Obama's Farewell Address."
}

\footnotetext{
19 "President Obama's Farewell Address."

20 "President Obama's Farewell Address."
} 
Table 2.

Types of internal conjunction

\begin{tabular}{|c|c|c|}
\hline $\begin{array}{c}\text { Internal } \\
\text { Conjunction }\end{array}$ & Linkers & Number \\
\hline Internal Addition & As well & 4 \\
Now & 5 \\
\hline $\begin{array}{c}\text { Internal } \\
\text { Comparison }\end{array}$ & Again & 4 \\
In fact & 1 \\
\hline Internal Time & Eventually & 2 \\
& First & 2 \\
& More & 1 \\
\hline Internal & After all & 2 \\
Consequence & & \\
\hline
\end{tabular}

\section{a. Internal Addition}

"The freedom to chase our individual dreams through our sweat, and toil, and imagination -and the imperative to strive together as well, to achieve a common good, a greater good." 21

One of the conjunction which express internal addition is the conjunction as well and it was used in the data above to synchronize the sentence in order to the reader will be able to understand more about what was being said.

"It's why Gls gave their lives at Omaha Beach and Iwo Jima; Iraq and Afghanistan -- and why men and women from Selma to Stonewall were prepared to give theirs as well."

\footnotetext{
21 "President Obama's Farewell Address."

22 "President Obama's Farewell Address."
}

As we can see in the data above that the conjunction as well was used in the of the sentence right before the full stop but it didn't reduce the meaning and the existence of the conjunction itself.

\section{b. Internal Comparison}

"And the good news is that today the economy is growing again. Wages, incomes, home values and retirement accounts are all rising again. Poverty is falling again." 23

The conjunction again which was used in the data above explained that idea might happen in same way or simply said that the repetition of the same event might happen. As we can see that there were three events which might occur in the data above.

\section{c. Internal Time}

"That order is now being challenged. First by violent fanatics who claim to speak for Islam More recently by autocrats in foreign capitals who seek free markets in open democracies and civil society itself as a threat to their power."24

The data above show first and more recently as sequential in begin and then it was doing in appropriate of the sequential before. The conjunction first and more recently in data above, gave explanation and example before where someone to do something. So, in the end, people get the result.

\footnotetext{
23 "President Obama's Farewell Address."

24 "President Obama's Farewell Address."
} 


\section{d. Internal Consequence}

"Health care costs are rising at the slowest rate in 50 years. And l've said, and I mean it, anyone can put together a plan that is demonstrably better than the improvements we've made to our health care system, that covers as many people at less cost, I will publicly support it. Because that, after all, is why we serve. Not to score points or take credit. But to make people's lives better."

The conjunction after all in the data above was used to justify an argument that is and l've said, and I mean it, anyone can put together a plan that is demonstrably better than the improvements we've made to our health care system that covers as many people at less cost, I will publicly support it. Therefore, as the consequence of the action is that they serve and what happened was the reason why they serve.

\section{Continuatives}

The continuative, it was found that there were only three linkers that were used in Barack Obama's farewell speech. All of the data which consisted of continuatives have been classified and could be seen on the table below:

Table 3 Types of continuatives

\begin{tabular}{|c|c|c|}
\hline Continuative & Linkers & Number \\
\hline $\begin{array}{c}\text { Addition } \\
\text { Continuative }\end{array}$ & Also & 2 \\
\hline
\end{tabular}

\begin{tabular}{|c|c|c|}
\hline $\begin{array}{c}\text { Comparison } \\
\text { Continuative }\end{array}$ & Only & 8 \\
\hline $\begin{array}{c}\text { Time } \\
\text { Continuative }\end{array}$ & Still & 5 \\
\hline
\end{tabular}

\section{a. Addition Continuative}

"That's the economic argument. But stark inequality is also corrosive to our democratic idea. While the top 1 percent has amassed a bigger share of wealth and income, too many of our families in inner cities and in rural counties have been left behind." 25

The data it showed that also as an additional linker to clarify the idea of the sentence. As it was explained before in chapter 2 that continuatives typically happen next to the finite verb within the clause. In this case, the characteristic of continuative was underlined as follow: is also corrosive.

\section{b. Comparison Continuative}

"Our youth, our drive, our diversity and openness, our boundless capacity for risk and reinvention means that the future should be ours. But that potential will only be realized if our democracy works." ${ }^{26}$

In the data above, the continuative only used to show expectancy of one potential that would just happen if one condition had been fulfilled. The indication of continuatives could be seen as follow: "will only be realized ..."

\footnotetext{
25 "President Obama's Farewell Address."

26 "President Obama's Farewell Address."
} 


\section{c. Time Continuative}

"So I first came to Chicago when I was in my early twenties, and I was still trying to figure out who I was; still searching for a purpose to my life. And it was a neighborhood not far from here where I began working with church groups in the shadows of closed steel mills."

In the data above, the continuatives still was used to describe that something could happen sooner or later, or persist longer, than one might expect. This explained that how his life was going at the past before he became a president of United State of America. The indicator of continuative of the data above as follows: was still trying...; still searching for.

From the results above, it is found that there were eighteen types which used in Obama's speech. Meanwhile in the internal conjunction the researcher found eight types that found in the speech. Then in continuatives the researcher found that there were three.

\section{External Conjunction}

The table below shows that the percentage of external conjunctions which were used in Obama's farewell speech. Addition conjunction was $64 \%$ of use in proportion to all uses of external conjunction. Then, the second highest number is consequence conjunction which appeared of 62 times (18\%). The type of external conjunction which is in the third highest number is comparison
$(12 \%)$. The remaining external conjunction comes as the lowest is time conjunction (5\%).

Table 4. Percentage of external conjunction

\begin{tabular}{|c|c|c|c|}
\hline $\begin{array}{c}\text { External } \\
\text { Conjunction }\end{array}$ & Linkers & Total & Percentage \\
\hline$\square$ Addition & $\square$ and, or & $\square 219$ & $\square 64 \%$ \\
\hline$\square$ Comparison & $\begin{array}{l}\square \text { but, in } \\
\text { other } \\
\text { words, } \\
\text { instead of }\end{array}$ & $\square 41$ & $\square 12 \%$ \\
\hline $\begin{array}{l}\square \text { Time } \\
\square \text { Consequence }\end{array}$ & $\begin{array}{l}\square \text { after, } \\
\text { when, } \\
\text { while }\end{array}$ & $\begin{array}{l}\square 18 \\
\square 62\end{array}$ & $\begin{array}{l}\square 5 \% \\
\square 18 \%\end{array}$ \\
\hline & $\begin{array}{l}\text { because, } \\
\text { however, } \\
\text { so, } \\
\text { although, } \\
\text { by, if, if- } \\
\text { then, } \\
\text { unless, } \\
\text { without, to }\end{array}$ & & \\
\hline
\end{tabular}

\section{Internal Conjunction}

The table below shows that the percentage of internal conjunction which were used in Obama's farewell speech. Addition conjunction was $43 \%$ of use in proportion to all uses of external conjunction. Then, the second highest numbers are comparison and time conjunction which appeared of 5 times of each (24\% each). The remaining type of internal conjunction comes as the lowest is consequence conjunction $(10 \%)$. 
Table no. 5. Percentage of internal conjunction

\begin{tabular}{|l|l|l|l|}
\hline $\begin{array}{c}\text { Internal } \\
\text { Conjunction }\end{array}$ & Linkers & Total & $\begin{array}{c}\text { Percen } \\
\text { tage }\end{array}$ \\
\hline$\square$ Addition & $\begin{array}{l}\square \text { as well, } \\
\text { now } \\
\square \text { Comparison } \\
\text { again, in } \\
\text { fact } \\
\square \text { eventually, } \\
\text { first, more } \\
\text { recently } \\
\text { Time }\end{array} \square 5$ & $\square 43 \%$ \\
$\square$ Consequence all & $\square 2$ & $\square 24 \%$ \\
$\square$ after \\
$\square$ Con \\
\hline
\end{tabular}

\section{Continuatives}

The table below shows that the percentage of continuatives which were used in Obama's farewell speech. Comparison continuative was $53 \%$ of use in proportion to all uses of continuatives. Then, the second highest number is time continuatives which appeared of 5 times (33\%). The remaining type of continuatives comes as the lowest is addition continuatives (13\%).

\section{Table $6 . \quad$ Percentage of continuatives}

\begin{tabular}{|l|l|l|l|}
\hline Continuatives & Linkers & Total & $\begin{array}{c}\text { Percen } \\
\text { tage }\end{array}$ \\
\hline$\square$ Addition & $\square$ Also & $\square 2$ & $\square 13 \%$ \\
$\square$ Comparison & $\square$ only & $\square 8$ & $\square 53 \%$ \\
$\square$ Time & $\square$ still & $\square 5$ & $\square 33 \%$ \\
\hline
\end{tabular}

Obama's farewell speech was one of example which contains of the types of conjunction. The types of conjunction expressions had been written in findings based on Martin Rose theory and interpretation by reading the some theories and some previous study in this research.

It is found 29 conjunctions which appeared in the speech which was uttered by Obama. The conjunctions were divided into three types: external conjunction, internal conjunction and continuative. For the external conjunction, the linkers which were used namely and, or, but, in other words, instead of, after, when, while, because, however, so, although, by, if, if-then, unless, without and to. For the internal conjunctions, the linkers were used namely as well, now, again, in fact, eventually, first, more recently and after all. The linkers of continuatives were mostly used in the speech namely also, only and still.

The explanation about the types of conjunction is an important role in order to decide the meaning and the functions of conjunction. It helped the reader understood about the meanings and functions of those conjunctions exactly because sometimes the same conjunctions had different meaning and function in one sentence and also in different situation.

The types of conjunction could help people understanding the logic meaning of conjunction and the functions of conjunctions could help the people comprehend the whole text. The conjunction consists of more than one meaning and one function which was depended on the certain situation. 


\section{Conclusion}

The types of conjunction which appeared are external conjunction, internal conjunction and continuatives that describes meaning of every expressions of the conjunction which they related the conjunction with some words, phrases, clause, and sentences.

External conjunctions are concerned with construing a sequence of activities in a text. It means that for each general type of external conjunction - addition, comparison, time and consequence - there are two or more sub-types. For the external conjunction, the linkers which were used namely and, or, but, in other words, instead of, after, when, while, because, however, so, although, by, if, if-then, unless, without, and to.

Internal conjunction deals with organizing the text itself. Internal conjunction includes the same four logical types as it has been shown in external conjunctions. The linkers used in this Obama's speech were as well, now, again, in fact, eventually, first, more recently and after all.

Continuatives are something that expresses or causes continuation. Logical relations realized by continuatives include addition, comparison and time. The linkers that were mostly used in the speech were also, only and still.

\section{References}

Bloor, Thomas, and Meriel Bloor. The Functional Analysis of English. London: Arnold, 1995.

Halliday, M. A. K., and Ruqaiya Hasan. Cohesion in English. London: Longman, 1976.

Hameed, Hind Tahseen. "Cohesion in Texts: A Discourse Analysis of a News Article in a Magazine." AlFaith Journal 37 (December 2008): 81-114.

Lorimor, Heidi. "Conjunction and Grammatical Agreement." Dissertation, University of Illinois at Urbana-Champaign, 2007.

Martin, J. R., and David Rose. Working with Discourse: Meaning Beyond the Clause. 2nd ed. London: British Library, 2007.

"President Obama's Farewell Address: Full Video and Text." The New York Times, January 20, 2018, sec.

U.S. https://www.nytimes.com/2017/0 1/10/us/politics/obama-farewelladdress-speech.html.

Ramlan, M. Morfologi Suatu Tinjauan Deskriptif. Yogyakarta: CV. Karyono, 1985.

Stern, George. An Outline of English Grammar: with Exercises and Answer Key. Singapore: Learners Pub., 2003. 
OKARA: Jurnal Bahasa dan Sastra, Vol. 12, No. 2, November 2018 212 